\title{
AMMONIA VOLATILIZATION IN NO-TILL SYSTEM IN THE SOUTH-CENTRAL REGION OF THE STATE OF PARANÁ, BRAZIL $^{(1)}$
}

\author{
Sandra Mara Vieira Fontoura ${ }^{(2)} \&$ Cimélio Bayer ${ }^{(3)}$
}

\begin{abstract}
SUMMARY
Ammonia $\left(\mathrm{NH}_{3}\right)$ volatilization can reduce the efficiency of urea applied to the surface of no-till (NT) soils. Thus, the objectives of this study were to evaluate the magnitude of $\mathrm{NH}_{3}$ losses from surface-applied urea and to determine if this loss justifies the urea incorporation in soil or its substitution for other $\mathrm{N}$ sources under the subtropical climatic conditions of South-Central region of Paraná State, Brazil. The experiment, performed over four harvesting seasons in a clayey Hapludox followed a randomized block design with four replicates. A single dose of $\mathrm{N}$ $\left(150 \mathrm{~kg} \mathrm{ha}^{-1}\right)$ to V5 growth stage of corn cultivated under NT system was applied and seven treatments were evaluated, including surface-applied urea, ammonium sulfate, ammonium nitrate, urea with urease inhibitor, controlled-release $\mathrm{N}$ source, a liquid $\mathrm{N}$ source, incorporated urea, and a control treatment with no $\mathrm{N}$ application. Ammonia volatilization was evaluated for 20 days after $\mathrm{N}$ application using a semiopen static system. The average cumulative $\mathrm{NH}_{3}$ loss due to the superficial application of urea was low (12.5\% of the applied N) compared to the losses observed in warmer regions of Southeastern Brazil (greater than $50 \%$ ). The greatest $\mathrm{NH}_{3}$ losses were observed in dry years (up to $25.4 \%$ of the applied $\mathrm{N}$ ), and losses decreased exponentially as the amount of rainfall after $\mathrm{N}$ application increased. Incorporated urea and alternative $\mathrm{N}$ sources, with the exception of controlled-release $\mathrm{N}$ source, decreased $\mathrm{NH}_{3}$ volatilization in comparison with surface-applied urea. Urea incorporation is advantageous for the reduction of $\mathrm{NH}_{3}$ volatilization; however, other aspects as its low operating efficiency should be considered before this practice is adopted. In the South-Central region of Paraná, the low $\mathrm{NH}_{3}$ losses from the surface-applied urea in NT system due to wet springs and mild temperatures do not justify its replacement for other $\mathrm{N}$ sources.
\end{abstract}

Index terms: nitrogen fertilizer, urea, corn, urease.

\footnotetext{
(1) Received for publication in September 2008 and approved in July 2010.

(2) Researcher of Agraria Foundation of Agricultural Research. Agraria Cooperative, Zip Code 85139-400, Entre Rios District, Guarapuava (PR), Brazil. E-mail: sandrav@agraria.com.br

${ }^{(3)}$ Professor of Department of Soil Science, Federal University of Rio Grande do Sul, Zip Code 91501-970, Porto Alegre (RS), Brazil. E-mail: cimelio.bayer@ufrgs.br
} 


\title{
RESUMO: VOLATILIZAÇÃODE AMÔNIA EMPLANTIODIRETONAREGIÃO CENTRO-SUL DO PARANÁ
}

\begin{abstract}
A volatilização de amônia $\left(\mathrm{NH}_{3}\right)$ pode resultar em baixa eficiência da ureia aplicada na superfície de solos sob plantio direto (PD). Os objetivos deste estudo foram avaliar a magnitude da perda de $\mathrm{NH}_{3}$ proveniente da ureia e verificar se essa perda justifica a incorporação do fertilizante ou a sua substituição por outras fontes de $N$ nas condições climáticas da região centro-sul do Paraná. O experimento, conduzido por quatro safras num Latossolo Bruno argiloso, consistiu da aplicação em dose única de $150 \mathrm{~kg} \mathrm{ha}^{-1}$ de Nem cobertura na cultura do milho (estádio V5) em PD, em sete tratamentos (ureia superficial, ureia incorporada, sulfato de amônio, nitrato de amônio, ureia com inibidor de urease, fonte de $N$ de liberação gradual e uma fonte líquida de $N$ ), além de um tratamento controle (sem adubação nitrogenada). Utilizou-se o delineamento de blocos casualizados, com quatro repetições. A volatilização de $\mathrm{NH}_{3}$ foi avaliada por meio do sistema semiaberto estático, durante 20 dias após a aplicação dos fertilizantes. A perda acumulada de $\mathrm{NH}_{3}$ com a aplicação superficial de ureia, na média dos quatro anos, foi baixa (12,5\% do N aplicado) em comparação a perdas superiores a $50 \%$ determinadas em regiões mais quentes do Sudeste do Brasil. As maiores perdas de $\mathrm{NH}_{3}$ da ureia foram verificadas em anos secos (até $25,4 \%$ do $N$ aplicado), as quais reduziram exponencialmente com o aumento do volume de chuva posterior à aplicação do $N$. A incorporação da ureia e as demais fontes de $N$, com exceção da fonte de $N$ de liberação gradual, reduziram a volatilização de $\mathrm{NH}_{3}$ em comparação à ureia superficial. A incorporação da ureia é tecnicamente vantajosa quanto à redução da volatilização de $\mathrm{NH}_{3}$, porém a adoção dessa prática deverá levar em consideração outros aspectos, como o seu baixo rendimento operacional. Por sua vez, a baixa perda de $\mathrm{NH}_{3}$ proveniente da ureia superficial nas condições regionais de primavera chuvosa e com temperatura amena não justifica economicamente sua substituição por outras fontes de $N$ na região centro-sul do Paraná.
\end{abstract}

Termos de indexação: adubação nitrogenada, ureia, milho, urease.

\section{INTRODUCTION}

In Brazil, the no-till (NT) system has been adopted on approximately 25 million ha and more than 12 million ha are located in the South Region (FEBRAPDP, 2008). Particulary, in the SouthCentral region of Paraná, NT farming occupies more than $90 \%$ of agricultural area. Corn plays a significant role in the success of the NT system due to the significant input of straw to the soil. Futhermore, the usual corn-soybean rotation in a onethird proportion also reduces diseases and pests, and facilitates weed control (Fontoura \& Bayer, 2009).

High corn yields can be achieved with an adequate $\mathrm{N}$ supply. For no-till soils, $\mathrm{N}$ amendments are often applied by surface coverage fertilization, and urea is the main used source of N. Upon addition to the soil, urea undergoes enzymatic hydrolysis (Cantarella, 2007), and $\mathrm{NH}_{2}$ is converted to $\mathrm{NH}_{4}{ }^{+}$. As a result, the $\mathrm{pH}$ of the soil surrounding the granules increases due to $\mathrm{H}^{+}$consumption, which increases $\mathrm{NH}_{3}$ volatilization (Kissel et al., 1988). Thus, N volatilization is favored by high urease activity in the surface layer of no-tilled soils (Barreto \& Westerman, 1989) and the presence of straw on the soil surface, which limits contact between the soil and the fertilizer (Menguel, 1996). However, high soil moisture, organic matter content and CEC levels in the surface layer of
NT soils are important factors increasing the buffer capacity of soil $\mathrm{pH}$ variation (Vieira et al., 2008) with possible effects decreasing $\mathrm{NH}_{3}$ volatilization (Ferguson et al., 1984).

In Southeastern Brazil, N- $\mathrm{NH}_{3}$ losses from surface-applied urea in NT soils range from 38 to $78 \%$ of the total N applied (Lara Cabezas et al., 1997a, b; Lara Cabezas et al., 2000; Costa et al., 2003). As a result, farmers and researchers question the efficiency of the surface-applied urea as a $\mathrm{N}$ source for corn in NT system. However, $\mathrm{N}$ losses due to volatilization are highly dependent on the climate and soil type (AlKanani et al., 1991; Sangoi et al., 2003). For instance, temperature affects the rate of the enzymatic hydrolysis of urea, and rainfall affects the dilution of alkalinity generated by urea hydrolise in soil. Moreover, rainfall influences soil moisture, which favors the diffusion of $\mathrm{NH}_{4}{ }^{+}$into soil and its adsorption to soil colloids (Rodrigues \& Kiehl, 1986). Soil type affects the $\mathrm{pH}$ and the retention of $\mathrm{NH}_{4}{ }^{+}$in the soil (Sangoi et al., 2003). Due to the aforementioned factors, average $\mathrm{NH}_{3}$ losses below $20 \%$ of the total $\mathrm{N}$ applied as urea or manure are observed in subtropical regions of Southern Brazil (Port et al., 2003; Basso et al., 2004; Da Ros et al., 2005). Thus, these lower N volatilization losses than in tropical regions of Southeast Brazil evidenced that regional studies are necessary to determine the most appropriate $\mathrm{N}$ fertilization management strategy (Da Ros et al., 2005). 
Urea incorporation has been shown to significantly reduce $\mathrm{NH}_{3}$ volatilization (Silva et al., 1995). Among alternative $\mathrm{N}$ sources, applications of ammonium sulfate and ammonium nitrate to the soil surface can reduce $\mathrm{NH}_{3}$ volatilization (Lara Cabezas et al., 1997a) due to acid-base reactions and the presence of $\mathrm{NO}_{3}$ and $\mathrm{SO}_{4}{ }^{2-}$ anions, which favor vertical $\mathrm{NH}_{4}{ }^{+}$soil displacement (Lara Cabezas et al., 1997a, b; Kiehl, 1989). Controlled-release sources of $\mathrm{N}$ and fertilizers containing urease inhibitors can be used to increase $\mathrm{N}$ efficiency; however, the results obtained from these fertilizers are highly variable and range from null or negative (Rozas et al., 1999) to positive (Clay et al., 1990).

The present study, performed over four harvest seasons, aimed to evaluate the magnitude of $\mathrm{NH}_{3}$ volatilization from surface-applied urea to a no-till clayey Hapludox under the mild subtropical conditions of the South-Central region of the State of Paraná, Brazil. Furthermore, we aimed to determine whether the incorporation of urea or the application of an alternative $\mathrm{N}$ source should be recommended in substitution of surface-applied urea in this region.

\section{MATERIAL AND METHODS}

The present study was conducted between 2004/05 and 2007/08 at the experimental area of Agraria Foundation of Agricultural Research, located in the Entre Rios district of the county of Guarapuava, State of Paraná, Brazil. According to Köeppen classification, the climate is humid subtropical, and a dry season does not occur in the study region. According to the meteorological station of Agraria Foundation, the annual precipitation and average temperature are $1,956 \mathrm{~mm}$ and $16.9{ }^{\circ} \mathrm{C}$, respectively. The soil is a Hapludox (Latossolo Bruno alumínico by the Brazilian Soil Classification System - Embrapa, 2006). The chemical attributes of the $0-10$ and $10-20 \mathrm{~cm}$ soil layers in the different years of the study are provided in table 1 .
The experiment consisted in a single dose of $150 \mathrm{~kg} \mathrm{ha}^{-1}$ of $\mathrm{N}$ applied by broadcasting at the V5 growth stage of corn under a no-till system. The following fertilizers were evaluated: urea, ammonium sulfate, ammonium nitrate, urea with urease inhibitor, controlled-release $\mathrm{N}$ source and a liquid $\mathrm{N}$ source, which was only evaluated during the last two harvests. In each year, a control treatment without $\mathrm{N}$ application and a treatment with incorporated urea were also evaluated. The urea was incorporated manually in a groove $15-20 \mathrm{~cm}$ from the corn row. The experiment was conducted according to a randomized block design, and treatments were applied to $24.0 \mathrm{~m}^{2}$ plots (six corn rows at $0.8 \mathrm{~m}$ spacing and $5 \mathrm{~m}$ long) in four replications.

In each trial, corn was preceded by wild radish (Raphanus raphanistrum L.), which was managed with glyphosate herbicide applied, at 1,000 $\mathrm{g} \mathrm{ha}^{-1}$ a.e., approximately 10 days prior to corn sowing. Pioneer 30 F53 hybrid corn was sown on 10/01/2004, 10/03/ 2005, 9/26/2006 and 9/28/2007 using a seed drill with a chisel-type furrowopener at a density of 65,000 plants $^{-1} \mathrm{~h}^{-1}$. Seeds were treated yearly with thiodicarb (700 g a.i. per $100 \mathrm{~kg}$ of seeds). Fertilization was performed according to the results of chemical soil analyses (Table 1), and the application of 350,390 , 400 and $350 \mathrm{~kg} \mathrm{ha}^{-1}$ of $10-20-20\left(\mathrm{~N}-\mathrm{P}_{2} \mathrm{O}_{5}-\mathrm{K}_{2} \mathrm{O}\right)$ was applied in 2004/05, 2005/06, 2006/07 and 2007/08, respectively. Post-emergence weed control was achieved with a mixture of atrazine, simazine and a mesotrione herbicides at a rate of 750, 750 and $120 \mathrm{~g} \mathrm{ha}^{-1}$ a.e., respectively.

To evaluate $\mathrm{NH}_{3}$ volatilization, five polyvinyl chloride (PVC) bases per plot were fixed between corn rows at a depth of $2.5 \mathrm{~cm}$ prior to $\mathrm{N}$ application. The bases were isolated with a plastic film during fertilizer application. Immediately after application, the plastic was removed and fertilizer was added to each PVC base. The objective of the plastic film and the posterior application of $\mathrm{N}$ in the PVC base was to reduce the variability of $\mathrm{NH}_{3}$ volatilization.

Table 1. Soil chemical attributes of the experimental areas during the four growing seasons

\begin{tabular}{|c|c|c|c|c|c|c|c|c|c|c|}
\hline Year & Depth & $p H^{(1)}$ & $\mathbf{H}+\mathbf{A l}$ & $\mathrm{Al}^{3+}$ & $\mathrm{Ca}^{2+}$ & $\mathrm{Mg}^{2+}$ & $\mathbf{K}^{+}$ & $\mathbf{P}$ & MO & V \\
\hline & $\mathrm{cm}$ & & & 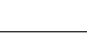 & $\mathrm{cmol}_{\mathrm{c}} \mathrm{dm}^{-3}$ & & - & $\mathrm{mg} \mathrm{dm}^{-3}$ & $\mathrm{~g} \mathrm{dm}-3$ & $\%$ \\
\hline $2004 / 05$ & $\begin{array}{r}0-10 \\
10-20\end{array}$ & $\begin{array}{l}4.80 \\
4.60\end{array}$ & $\begin{array}{l}7.76 \\
9.01\end{array}$ & $\begin{array}{l}0.08 \\
0.27\end{array}$ & $\begin{array}{l}7.05 \\
4.76\end{array}$ & $\begin{array}{l}1.62 \\
1.54\end{array}$ & $\begin{array}{l}0.44 \\
0.26\end{array}$ & $\begin{array}{r}16.0 \\
5.7\end{array}$ & $\begin{array}{l}60.30 \\
53.61\end{array}$ & $\begin{array}{l}54.0 \\
42.1\end{array}$ \\
\hline $2005 / 06$ & $\begin{array}{r}0-10 \\
10-20\end{array}$ & $\begin{array}{l}4.80 \\
4.70\end{array}$ & $\begin{array}{l}9.01 \\
9.70\end{array}$ & $\begin{array}{l}0.04 \\
0.08\end{array}$ & $\begin{array}{l}3.64 \\
3.71\end{array}$ & $\begin{array}{l}1.25 \\
1.05\end{array}$ & $\begin{array}{l}0.50 \\
0.49\end{array}$ & $\begin{array}{r}14.5 \\
5.8\end{array}$ & $\begin{array}{l}56.28 \\
53.66\end{array}$ & $\begin{array}{l}35.6 \\
35.1\end{array}$ \\
\hline $2006 / 07$ & $\begin{array}{r}0-10 \\
10-20\end{array}$ & $\begin{array}{l}5.00 \\
4.50\end{array}$ & $\begin{array}{l}6.69 \\
8.36\end{array}$ & $\begin{array}{l}0.00 \\
0.34\end{array}$ & $\begin{array}{l}6.56 \\
3.87\end{array}$ & $\begin{array}{l}2.16 \\
0.91\end{array}$ & $\begin{array}{l}0.43 \\
0.28\end{array}$ & $\begin{array}{r}11.5 \\
8.0\end{array}$ & $\begin{array}{l}57.77 \\
67.08\end{array}$ & $\begin{array}{l}57.8 \\
37.7\end{array}$ \\
\hline $2007 / 08$ & $\begin{array}{r}0-10 \\
10-20\end{array}$ & $\begin{array}{l}5.20 \\
4.80\end{array}$ & $\begin{array}{l}5.76 \\
8.36\end{array}$ & $\begin{array}{l}0.00 \\
0.04\end{array}$ & $\begin{array}{l}6.12 \\
4.61\end{array}$ & $\begin{array}{l}2.99 \\
1.74\end{array}$ & $\begin{array}{l}0.47 \\
0.38\end{array}$ & $\begin{array}{r}12.8 \\
6.1\end{array}$ & $\begin{array}{l}69.13 \\
63.67\end{array}$ & $\begin{array}{l}62.4 \\
44.6\end{array}$ \\
\hline
\end{tabular}

(1) $\mathrm{CaCl}_{2} 0.05 \mathrm{~mol} \mathrm{~L}^{-1}$. The analysis was carried out according to the procedures described in Tedesco et al. (1995). 
$\mathrm{N}-\mathrm{NH}_{3}$ volatilization was evaluated with a semiopen static collector (Lara Cabezas \& Trivelin, 1990) made of a transparent acrylic chamber $(\varnothing=0.15 \mathrm{~m}$ and $\mathrm{h}=0.35 \mathrm{~m}$ ). The collector was installed over the bases, and the evaluation performed at $0,1,3,5,9$ and 20 days after $\mathrm{N}$ application. During the evaluation period, the chamber was transferred to an adjacent base to ensure that the measured period reflected the environmental conditions (rain, wind, temperature) of the previous period and to prevent interferences caused by the chamber (Cantarela et al., 1999). A plastic support was installed on the top of the chamber in order to avoid rain (Da Ros et al., 2005).

Two absorbing sponge disks were placed inside the chamber $\left(2.0 \mathrm{~cm}\right.$ thick and soaked in $0.05 \mathrm{~mol} \mathrm{~L}^{-1}$ sulfuric acid and $2 \%$ glycerin). The first disk was placed $14 \mathrm{~cm}$ from the bottom of the chamber to capture volatilized $\mathrm{NH}_{3}$ from the soil, and the second disk was placed $8 \mathrm{~cm}$ below the top of the cylinder to prevent $\mathrm{NH}_{3}$ from the atmosphere from entering the chamber and contaminating the lower sponge. Amonium was extracted from the lower disk by five successive washes with $1.0 \mathrm{~mol} \mathrm{~L}^{-1} \mathrm{KCl}$. The washings were collected in a volumetric flask, and the final volume of the solution was increased to $200 \mathrm{~mL}$. To a $20 \mathrm{~mL}$ aliquot of the solution, $0.2 \mathrm{~g}$ of $\mathrm{MgO}$ was added, and the mixture was steam distilled in a semi-micro Kjeldahl. $\mathrm{NH}_{3}{ }^{+}$was converted to $\mathrm{NH}_{4}$ in a $\mathrm{H}_{3} \mathrm{BO}_{3}$ solution, which was quantified by titration with a standard sulfuric acid solution (Tedesco et al., 1995). The amount of volatilized $\mathrm{N}-\mathrm{NH}_{3}$ was calculated based on the total volume $(200 \mathrm{~mL})$ of the washings, and the results were expressed in daily rates (kg ha-1 day $^{-1}$ ) of $\mathrm{N}-\mathrm{NH}_{3}$. Volatilization rates from the control treatment (without $\mathrm{N}$ fertilizer) were subtracted, and cumulative $\mathrm{N}-\mathrm{NH}_{3}$ losses from each $\mathrm{N}$ source were calculated $\left(\mathrm{kg} \mathrm{ha}^{-1}\right)$ and expressed as a percent of the applied $\mathrm{N}$.

The yield of corn grain was evaluated by manually harvesting a $12.8 \mathrm{~m}^{2}$ area (four central corn rows), and the data was expressed at $13 \%$ humidity. Rainfall and air temperature data was obtained from the meteorological station of Agraria Fundation, which is located 500 to $1,000 \mathrm{~m}$ from the experimental area.

The corn yield and cumulative $\mathrm{N}-\mathrm{NH}_{3}$ volatilization (as a percentage of applied $\mathrm{N}$ ) results were subjected to an analysis of variance. The differences between the treatment means were evaluated by Tukey test at $5 \%$.

\section{RESULTS AND DISCUSSION}

Average monthly temperatures in November, month that $\mathrm{N}$ fertilizers were applied each year, showed a very little variation among years, varying from 18.1 to $18.9{ }^{\circ} \mathrm{C}$ (Figure 1). A few higher temperature was observed in the second (2005/06) and third years (2006/07). On the other hand, significant variations were observed in the volume of precipitation, which varied from 58.6 to $185.0 \mathrm{~mm}$. As shown in Figure 1, the driest years coincided with the highest temperatures (2005/06 and 2006/07). Theoretically, the second and third years had the greatest potential for nitrogen loss due to $\mathrm{NH}_{3}$ volatilization because high temperatures accelerate the enzymatic hydrolysis of urea due to an increase in urease activity, and low volumes of precipitation result in low soil moisture, which reduces $\mathrm{NH}_{4}{ }^{+}$ diffusion into the soil (Rodrigues \& Kiehl, 1986).

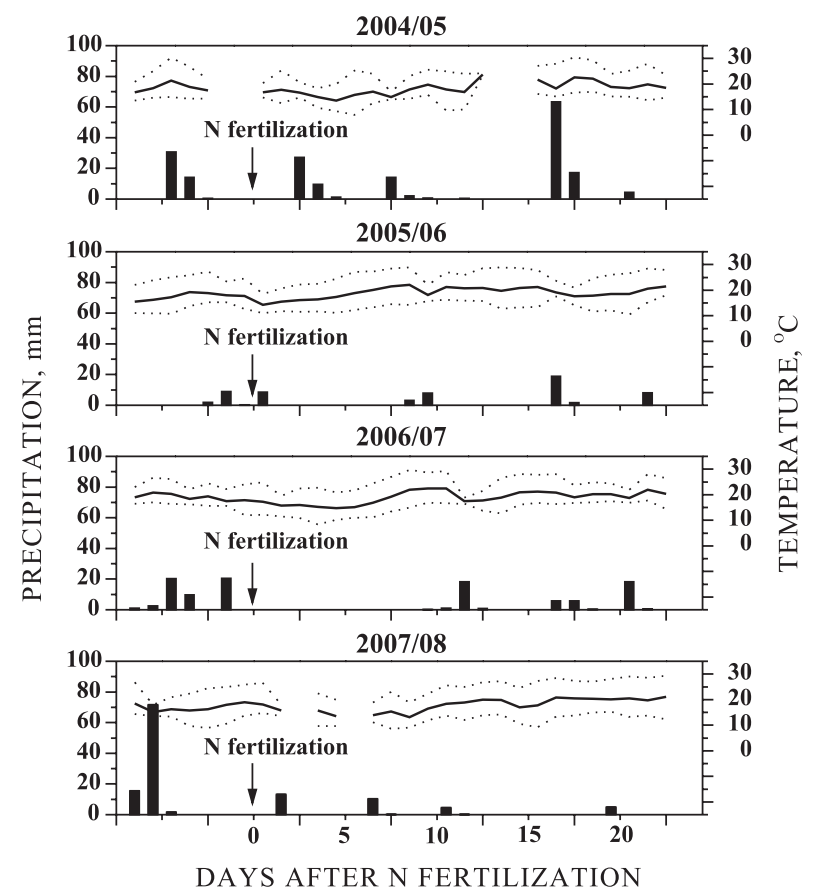

Figure 1. Pluviometric precipitation (vertical bars) and air temperature (minimum, average and maximum) for the month of November during four growing seasons in Guarapuava, PR.

\section{Daily rates and cumulative losses of $\mathrm{N}-\mathrm{NH}_{3}$ due to the surface application of urea}

The volatilization rate and cumulative losses of $\mathrm{N}-\mathrm{NH}_{3}$ due to the surface application of urea varied among years (Figure 2). The greatest volatilization rates and cumulative $\mathrm{N}-\mathrm{NH}_{3}$ losses were observed in the second and third years due to low volumes of precipitation and high average temperatures (Figure 2, Table 2). Three days after $\mathrm{N}$ application, the volatilization rates were approximately $8 \mathrm{~kg} \mathrm{ha}^{-1}$ day $^{-1}$ in both the second and third years, and cumulative losses of $\mathrm{N}-\mathrm{NH}_{3}$ in 2005/06 and 2006/07 were 25.4 and $20.1 \%$ of the total applied $\mathrm{N}$, respectively (Table 2). In 2004/05 and 2007/08, cumulative $\mathrm{NH}_{3}$ losses were equal to 1.3 and $3.0 \%$ of the total applied N, respectively (Table 2). 

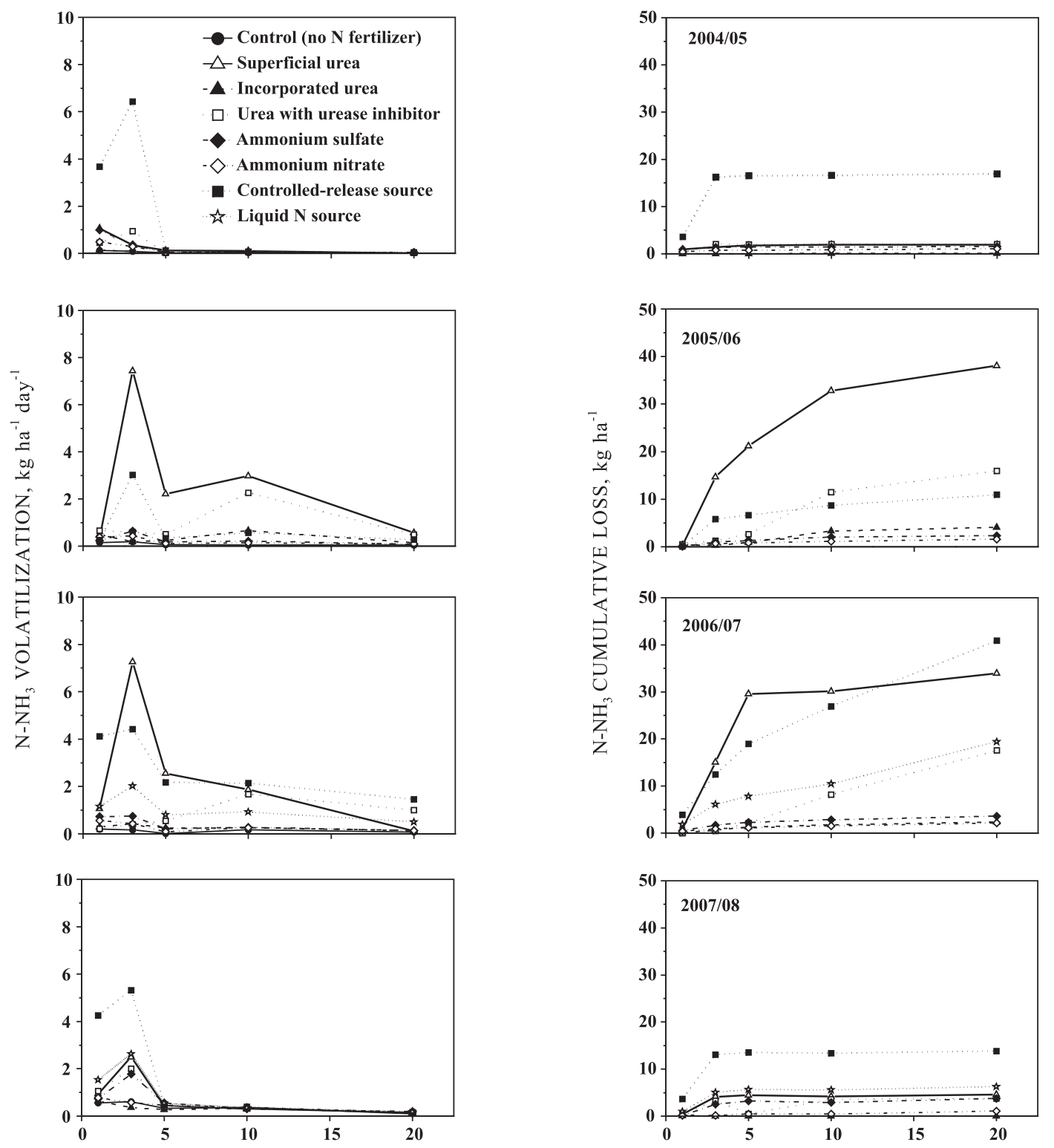

DAYS AFTER N FERTILIZATION

Figure 2. Rate and cumulative loss of $\mathrm{N}-\mathrm{NH}_{3}$ by volatilization during four harvest seasons (2004/05, 2005/06, 2006/07 and 2007/08) of no-till corn treated with urea (superficial and incorporated) and other $\mathrm{N}$ sources in Guarapuava, PR.

Cumulative $\mathrm{N}-\mathrm{NH}_{3}$ losses from all four years were averaged, and the results indicated that losses from surface-applied urea were equal to $12.5 \%$ (Table 2 ). This value is similar to the results $(13.6 \%)$ obtained by Rozas et al. (1999), who studied $\mathrm{NH}_{3}$ volatilization in the Balcarce region of Argentina, which has an annual rainfall and average annual temperature of $870 \mathrm{~mm}$ and $13.7^{\circ} \mathrm{C}$, respectively. Moreover, the results of the present study were slightly lower than those $(17 \%)$ reported by Da Ros et al. (2005), who evaluated a sandy soil in the Central Depression region of the State of Rio Grande do Sul, Brazil, which has an annual rainfall and average annual temperature of $1,769 \mathrm{~mm}$ and $19.3^{\circ} \mathrm{C}$, respectively.
In previous field studies conducted in the Southern region of Brazil, manure was applied as an $\mathrm{N}$ source, and cumulative $\mathrm{N}$ losses ranging from 6.5 to $26 \%$ of ammoniacal N were observed (Port et al., 2003; Basso et al., 2004). Moreover, N losses in subtropical climates were significantly lower than those obtained in tropical climates (38 to $78 \%$ ) (annual average temperature $\sim 22{ }^{\circ} \mathrm{C}$ ), such as Uberlândia (Lara Cabezas et al., 1997a, b; Lara Cabezas et al., 2000) and Piracicaba (Costa et al., 2003), which is located in Southeast Brazil. The aforementioned results indicated that the magnitude of $\mathrm{N}$ loss due to $\mathrm{NH}_{3}$ volatilization in notill soils in Southern Brazil is significantly lower than those observed in regions with a warmer climate. 
Table 2. Cumulative ammonia loss $\left(\mathrm{N}_{-} \mathrm{NH}_{3}\right)$, average corn yield, relative grain yield, and average temperature and volume of precipitation in November and in the first five days prior to and after fertilization

\begin{tabular}{|c|c|c|c|c|c|c|c|}
\hline \multirow[t]{2}{*}{$\mathbf{N}$ source } & \multirow[t]{2}{*}{ 2004/05 } & \multirow[t]{2}{*}{$2005 / 06$} & $2006 / 07$ & $2007 / 08$ & Average & \multicolumn{2}{|c|}{ Average yield } \\
\hline & & & \multicolumn{3}{|c|}{$\%$ of applied nitrogen } & $\mathrm{t} \mathrm{ha}^{-1}$ & $\%^{(1)}$ \\
\hline Control (no N) & - & - & - & - & - & $11.7 \mathrm{~b}$ & 100 \\
\hline Superficial urea & $1.3 \mathrm{~b}$ & $25.4 \mathrm{a}$ & $20.1 \mathrm{ab}$ & $3.0 \mathrm{bc}$ & 12.5 & $14.0 \mathrm{a}$ & 120 \\
\hline Incorporated urea & $0.1 \mathrm{c}$ & $2.7 \mathrm{~d}$ & $1.6 \mathrm{~d}$ & $0.0 \mathrm{~d}$ & 1.1 & $14.2 \mathrm{a}$ & 122 \\
\hline Ammonium sulfate & $1.0 \mathrm{bc}$ & $1.6 \mathrm{~d}$ & $2.4 \mathrm{~d}$ & $2.5 \mathrm{bcd}$ & 1.9 & $14.3 \mathrm{a}$ & 123 \\
\hline Ammonium nitrate & $0.7 \mathrm{bc}$ & $1.0 \mathrm{~d}$ & $1.4 \mathrm{~d}$ & $0.7 \mathrm{bcd}$ & 1.0 & $14.1 \mathrm{a}$ & 121 \\
\hline Urea with urease inhibitor & $1.4 \mathrm{~b}$ & $10.7 \mathrm{~b}$ & $11.7 \mathrm{c}$ & $2.5 \mathrm{~cd}$ & 6.6 & $14.5 \mathrm{a}$ & 124 \\
\hline Controlled - release source & $11.3 \mathrm{a}$ & $7.3 \mathrm{c}$ & $27.3 \mathrm{a}$ & $9.3 \mathrm{a}$ & 13.8 & $14.4 \mathrm{a}$ & 123 \\
\hline Liquid source of $\mathrm{N}$ & - & - & $12.9 \mathrm{bc}$ & $4.2 \mathrm{~b}$ & 8.6 & $15.0 \mathrm{a}$ & 129 \\
\hline Average & 2.6 & 8.1 & 11.1 & 3.2 & 6.3 & 13.9 & \\
\hline Coefficient of variation (\%) & 22.1 & 28.9 & 43.1 & 46.5 & & 4.4 & \\
\hline Average temperature $\left({ }^{\circ} \mathrm{C}\right)$ & 18.3 & 18.7 & 18.9 & 18.1 & & & \\
\hline $\operatorname{Rain}(\mathrm{mm})$ & 185.0 & 58.6 & 104.8 & 22.4 & & & \\
\hline Prior rain (mm) & 45.0 & 19.2 & 50.4 & 13.2 & & & \\
\hline After rain (mm) & 38.0 & 0.0 & 0.0 & 5.2 & & & \\
\hline
\end{tabular}

(1) In comparison to the control treatment. Averages followed by the same letter in a column do not differ according to the Tukey test at $5 \%$ level.

Among the evaluated years, the volume of rain that occurred within five days after $\mathrm{N}$ application affected $\mathrm{N}$ volatilization (Table 2 and Figure 3). Cumulative $\mathrm{N}$ losses due to the application of urea $(\%$ of applied $\mathrm{N}$ ) decreased exponentially as the volume of rain that fell after fertilization increased (Figure 3). However, a relationship between volatilization and the total monthly volume of precipitation or the volume of rain that fell five days prior to $\mathrm{N}$ application was not observed. These results were similar to those obtained by Lara Cabezas et al. (1997a), who demonstrated that $\mathrm{NH}_{3}$ emissions can be reduced by irrigating the crop after nitrogen application. Moreover, irrigation prior to fertilization did not have an effect on $\mathrm{N}$ losses. Precipitation after urea application was highly effective at distributing $\mathrm{NH}_{4}{ }^{+}$ to soil microsites with a lower $\mathrm{pH}$, which contributed to the adsorption of ions to soil colloids. Rainfall also transported fertilizer on the straw to the surface of the soil (Lara Cabezas et al., 1997a).

When precipitation occurred after fertilizer application (2004/05 and 2007/08), the daily $\mathrm{N}$ volatilization rate and the cumulative losses of $\mathrm{NH}_{3}$ throughout the 20 days evaluation period was significantly different from the results obtained when rainfall did not occur after application (2005/06 and 2006/07) (Figure 2). The lack of rain after $\mathrm{N}$ application affected the $\mathrm{N}$ volatilization process throughout the entire 20 day evaluation period; however, the rate of volatilization decreased over time. Alternatively, when rainfall followed $\mathrm{N}$ application, $\mathrm{NH}_{3}$ volatilization was restricted for the period of three days after fertilization. Therefore, in years when rainfall did not occur after urea application, the greatest losses of $\mathrm{N}$ through $\mathrm{NH}_{3}$ volatilization were due to high volatilization rates immediately after application as well as the prolongation of the volatilization period (Figure 2).

\section{Effects of urea incorporation and other $\mathrm{N}$ sources on $\mathrm{N}-\mathrm{NH}_{3}$ volatilization}

The efficiency of urea incorporation and the effect of $\mathrm{N}$ sources decreasing $\mathrm{N}$ losses can be better evaluated if the data from dry and warm years is mainly considered (second and third years), which showed the highest values of $\mathrm{NH}_{3}$ volatilization. On average, in the second and third years, cumulative $\mathrm{N}-\mathrm{NH}_{3}$ losses of incorporated urea, ammonium sulfate and ammonium nitrate decreased from $22.8 \%$ of applied N to 2.2, 2.0 and $1.2 \%$, respectively (Figure 2, Table 2).

The reduction of $\mathrm{NH}_{3}$ volatilization by urea incorporation is due to buffering effects of the soil $\mathrm{pH}$, which results from increased fertilizer-soil contact (Rodrigues \& Kiehl, 1986; Silva et al., 1995; Lara Cabezas et al., 1997b; Lara Cabezas et al., 2000; Sangoi et al., 2003). In contrast to the effects of urea hydrolysis, ammonium sulfate and ammonium nitrate reduce $\mathrm{NH}_{3}$ volatilization because they do not increase the $\mathrm{pH}$ of the soil surrounding the granule when they dissolve (Ferguson et al., 1984; Cantarella, 2007). Another factor that contributes to reduced ammonia losses from ammonium sulfate and ammonium nitrate is the presence of $\mathrm{SO}_{4}{ }^{2-}$ and $\mathrm{NO}_{3}{ }^{-}$anions, which favor the migration of $\mathrm{NH}_{4}{ }^{+}$to regions with a lower $\mathrm{pH}$ and the retention of ammonia in soil colloids (Fenn \& Hossner, 1985).

In general, controlled-release, liquid and urea with urease inhibitor $\mathrm{N}$ sources provided $\mathrm{NH}_{3}$ losses that were less than those of surface-applied urea and greater than those of ammonium sulfate and ammonium nitrate (Figure 2, Table 2). In drier years (second and third years), average $\mathrm{N}$ losses of urea with urease inhibitor, controlled-release and liquid sources were $11.2,17.3$ and $12.9 \%$ (only third year) of the total 
applied N, respectively. Compared to superficial urea treatment, these products reduced $\mathrm{N}$ volatilization from 51, 24 and $43 \%$ (Table 2). However, in years with greater volumes of precipitation, controlledrelease $\mathrm{N}$ sources presented cumulative losses that were higher than those of surface applied urea (Figure 2, Table 2). Across the four years, $\mathrm{N}$ losses of $13.8 \%$ of the total applied $\mathrm{N}$ were observed with controlled-release $\mathrm{N}$ source, which was higher than that of surface-applied urea (12.5\% of applied $\mathrm{N})$.

\section{Corn grain yields}

Surface $\mathrm{N}$ fertilization increased corn yield in all four years, but significant differences among $\mathrm{N}$ sources were not observed (Table 2). On average, $\mathrm{N}$ fertilization increased corn yield by $23 \%$, compared to the yield obtained from the control treatment $\left(11.7 \mathrm{t} \mathrm{ha}^{-1}\right)$.

The results obtained from all four years were analyzed, and a relationship between relative corn yield and cumulative $\mathrm{N}$ losses (\% of applied $\mathrm{N}$ ) was not observed, which probably was due to the high capacity of soil to $\mathrm{N}$ supply that is supported by high levels of soil organic matter (Table 1) and high corn yield of the control treatment without $\mathrm{N}$ fertilization (11.7 $\left.\mathrm{t} \mathrm{ha}^{-1}\right)$. Thus, an application of $150 \mathrm{~kg} \mathrm{ha}^{-1}$ of $\mathrm{N}$ was greater than the amount of $\mathrm{N}$ demanded by the crop. Furthermore, the use of wild radish as the preceding crop played a significant role in supplying $\mathrm{N}$ to corn. Specifically, the recycling of biomass and the release of $\mathrm{N}$ via the decomposition of vegetal residues with low $\mathrm{C}: \mathrm{N}$ ratio increased the $\mathrm{N}$ supply (Fontoura \& Bayer, 2009).

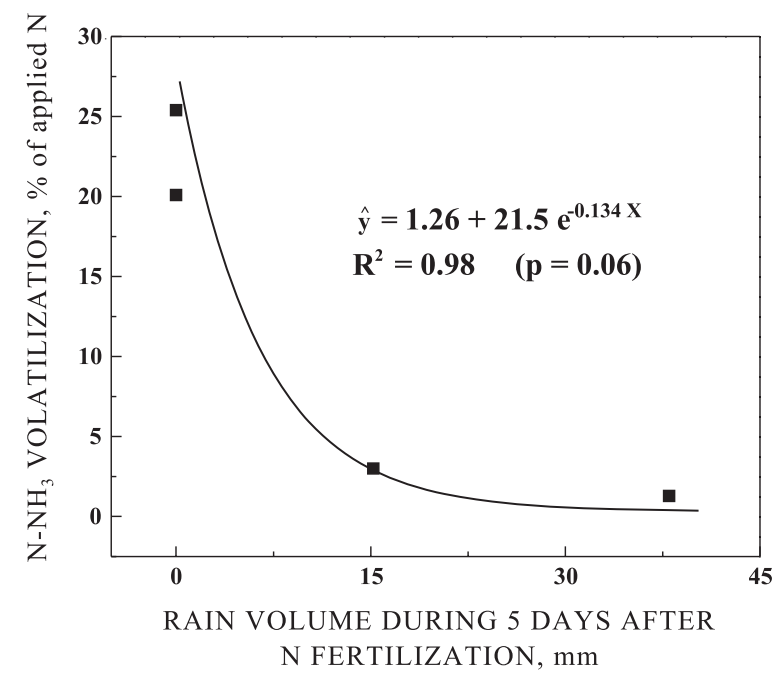

Figure 3. The relationship between the volume of rainfall in the five day period after superficial urea application and the cumulative ammonia volatilization in the 20 day period after $\mathrm{N}$ application $\left(150 \mathrm{~kg} \mathrm{ha}^{-1}\right)$ in a no-till corn. Each data point refers to a harvest year.

\section{Economic aspects}

Except for controlled-release N, alternative $\mathrm{N}$ sources reduced $\mathrm{NH}_{3}$ volatilization by $3.9 \%$ (liquid $\mathrm{N}$ source) to $11.5 \%$ (ammonium nitrate) in comparison to surface-applied urea. Based on the market values of these products over the past ten years, the cost of ammonium sulfate and ammonium nitrate per unit of $\mathrm{N}$ is $20 \%$ greater than that of urea (USDA/ESR, 2008). Moreover, the cost of urea with urease inhibitor, controlled-release $\mathrm{N}$ and liquid $\mathrm{N}$ is 15 and $150 \%$ higher than that of urea. Therefore, the additional cost of alternative $\mathrm{N}$ fertilizers is greater than the corresponding reduction in $\mathrm{N}$ volatilization. Thus, substitution of urea in the South-Central region of the State of Paraná is not economical.

Alternatively, urea incorporation, which costs $\mathrm{R} \$$ 18.80 per ha, is cheaper than the cost of the $\mathrm{N}$ lost by volatilization due to superficial application of urea ( $\mathrm{R} \$ 45.00$ per ha, considering the loss of $12.5 \%$ of $150 \mathrm{~kg} \mathrm{ha} \mathrm{a}^{-1} \mathrm{~N}$ at a cost of $\mathrm{R} \$ 2.4 \mathrm{~kg}^{-1}$ of $\mathrm{N}$ ). However, factors other than the costs of urea incorporation should be considered before this method is adopted. For instance, the operational efficiency of $\mathrm{N}$ incorporation is lower $\left(\sim 3 \mathrm{ha} \mathrm{h}^{-1}\right)$ than that of surface applications $\left(\sim 12 \mathrm{ha} \mathrm{h}^{-1}\right)$. Due to the low operational efficiency of urea incorporation, this method is not indicated for the cultivation of large fields.

\section{CONCLUSIONS}

1. On average of the four harvesting seasons, the surface application of urea to no-till corn in the SouthCentral region of the State of Paraná resulted in N losses of $12.5 \%$ of the total applied N. Moreover, greater losses were observed when lower volumes of rain fell after fertilization.

2. Urea incorporation and the use of ammonium sulfate, ammonium nitrate, liquid $\mathrm{N}$ source, and a urea with urease inhibitor reduced ammonia volatilization. However, reduction of $\mathrm{NH}_{3}$ volatilization was not observed with a controlledrelease $\mathrm{N}$ source that showed an average volatilization higher than that observed to surface-applied urea.

3 . The loss of $\mathrm{N}$ through volatilization of surfaceapplied urea was low; thus, fertilizer replacement is not necessary in the South-Central region of the State of Paraná. The incorporation of urea is economically advantageous; however, other aspects of this practice, such as low operational efficiency, should be considered.

\section{LITERATURE CITED}

AL-KANANI, T.; MACKENZIE, A.F. \& BARTHAKUR, N.N. Soil water and ammonia volatilization relationships with surface-applied nitrogen fertilizer solutions. Soil Sci. Soc. Am. J., 55:1761-1766, 1991. 
BARRETO, H.J. \& WESTERMAN, R.L. Soil urease activity in winter wheat residue management systems. Soil Sci. Soc. Am. J., 53:1455-1458, 1989.

BASSO, C.J.; CERETTA, C.A.; PAVINATO, P.S. \& SILVEIRA, M.J. Perdas de nitrogênio de dejeto líquido de suínos por volatilização de amônia. Ci. Rural, 34:1773-1778, 2004.

CANTARELLA, H. Nitrogênio. In: NOVAIS, R.F.; ALVAREZ V., V.H.; BARROS, N.F.; FONTES, R.L.F.; CANTARUTTI, R.B. \& NEVES, J.C.L., eds. Fertilidade do solo. Viçosa, MG, Sociedade Brasileira de Ciência do Solo, 2007. p.375470.

CANTARELlA, H.; ROSSETO, R.; BARBOSA, W.; PENNA, M.J. \& RESENDE, L.C.L. Perdas de nitrogênio por volatilização da amônia e resposta da cana-de-açucar à adubação nitrogenada, em sistemas de colheita de cana sem queima prévia. In: CONGRESSO NACIONAL DA STAB, 7., Londrina, 1999. Anais. Londrina, 1999. p.82-87.

CLAY, D.E.; MALZER, G.L. \& ANDERSON, J.L. Ammonia volatilization from urea as influenced by soil temperature, soil water content, and nitrification and hydrolysis inhibitors. Soil Sci. Soc. Am. J., 54:263-266, 1990.

COSTA, M.C.G.; VITTI, G.C. \& CANTARELLA, H. Volatilização de $\mathrm{N}-\mathrm{NH}_{3}$ de fontes nitrogenadas em cana-de-açúcar colhida sem despalha a fogo. R. Bras. Ci. Solo, 27:631637, 2003.

DA ROSS C.O.; AITA, C. \& GIACOMINI, S.J. Volatilização de amônia com aplicação de uréia na superfície do solo, no sistema plantio direto. Ci. Rural, 35:799-805, 2005.

EMPRESA BRASILEIRA DE PESQUISA AGROPECUÁRIA EMBRAPA. Centro Nacional de Pesquisa Agropecuária Solos. Sistema brasileiro de classificação de solos. 2.ed. Brasília, Embrapa Produção de Informação, 2006. 306p.

FEBRAPDP. Evolução da área em plantio direto no Brasil. Disponível em: <http://www.febrapdp.org.br/arquivos/ BREvolucaoPD72a06.pdf>. Acesso em: 22 ago. 2008.

FENN, L.B. \& HOSSNER, L.R. Ammonia volatilization from ammonium or ammonium-forming nitrogen fertilizers. Adv. Soil Sci., 1:124-169, 1985.

FERGUSON, R.B.; KISSEL, D.E.; KOELLIKER, J.K. \& BASEL, W. Ammonia volatilization from surface-applied urea: Effect of hydrogen ion buffering capacity. Soil Sci. Soc. Am. J., 2:578-582, 1984.

FONTOURA, S.M.V. \& BAYER, C. Adubação nitrogenada para alto rendimento de milho em plantio direto na região Centro-Sul do Paraná. R. Bras. Ci. Solo, 33:1721-1732, 2009.

KIEHL, J.C. Distribuição e retenção da amônia no solo após aplicação de uréia. R. Bras. Ci. Solo, 13:75-80, 1989.

KISSEL, D.E.; CABRERA, M.L. \& FERGUSON, R.B. Reactions of ammonia and urea hydrolysis products with soil. Soil Sci. Soc. Am. J., 52:1793-1796, 1988.
LARA CABEZAS, W.A. \& TRIVELIN, P.C.O. Eficiência de um coletor semi-aberto estático na quantificação de $\mathrm{N}-\mathrm{NH}_{3}$ volatilizado da uréia aplicada ao solo. R. Bras. Ci. Solo, 14:345-352, 1990

LARA CABEZAS, W.A.R.; KORNDÖRFER, G.H. \& MOTTA, S.A. Volatilização de $\mathrm{N}-\mathrm{NH}_{3}$ na cultura de milho: I. Efeito da substituição parcial da uréia por sulfato de amônio. $\mathrm{R}$. Bras. Ci. Solo, 21:481-487, 1997a.

LARA CABEZAS, W.A.R.; KORNDÖRFER, G.H. \& MOTTA, S.A. Volatilização de $\mathrm{N}-\mathrm{NH}_{3}$ na cultura de milho: II. Avaliação de fontes sólidas e fluídas em sistema de plantio direto e convencional. R. Bras. Ci. Solo, 21:489-496, $1997 \mathrm{~b}$.

LARA CABEZAS, W.A.R.; TRIVELIN, P.C.O.; KONDÖRFER, G.H. \& PEREIRA, S. Balanço da adubação nitrogenada sólida e fluída de cobertura na cultura do milho, em sistema de plantio direto no triângulo mineiro (MG). R. Bras. Ci. Solo, 24:363-376, 2000.

MENGEL, D. Manejo de nutrientes na cultura do milho de alta produtividade. Piracicaba, Potafós, 1996. 16p. (Informações Agronômicas, 73)

PORT, O.; AITA, C. \& GIACOMINI, S.J. Perda de nitrogênio por volatilização de amônia com o uso de dejetos de suínos em plantio direto. Pesq. Agropec. Bras., 38:857-865, 2003.

RODRIGUES, M.B. \& KIEHL, J.C. Volatilização de amônia após emprego de uréia em diferentes doses e modos de aplicação. R. Bras. Ci. Solo, 10:37-43, 1986.

ROZAS, H.S.; ECHEVERRIA, H.E.; STUDDERT, G.A. \& ANDRADE, F.H. No-till maize nitrogen uptake and Yield: Effect of urease inhibitor and application time. Agron. J., 91:950-955, 1999 .

SANGOI, L.; ERNANI, P.R.; LECH, V.A. \& RAMPAZZO, C. Volatililização de $\mathrm{N}-\mathrm{NH}_{3}$ em decorrência da forma de aplicação de uréia, manejo de resíduos e tipo de solo, em laboratório. Ci. Rural, 33:687-692, 2003.

SILVA, A.J.; LIMA JÚNIOR, M.A.; BISSANI, C.A.; BOHNEN, H. \& VOLKWEISS, S.J. Perdas de amônia por volatilização proveniente da uréia aplicada a solos dos trópicos úmidos. R. Bras. Ci. Solo, 19:141-144, 1995.

TEDESCO, M.J.; GIANELLO, C.; BISSANI, C.A.; BOHNEN, H. \& VOLKWEISS, S.J. Análise de solo, plantas e outros materiais. Porto Alegre, Universidade Federal do Rio Grande do Sul, 1995. 174p.

USDA/ESR. 2008. Average U.S. farm prices of selected fertilizers for 1960 to 2006. Disponível em: <www.usda.gov/Data/FertilizerUse> (Table7.xls, verificado em 1 Setembro, 2008)

VIEIRA, F.C.B.; BAYER, C.; MIELNICZUK, J.; ZANATTA, J.A. \& BISSANI, C.A. Long-term acidification of a Brazilian Acrisol as affected by no till cropping systems and nitrogen fertilizer. Austr. J. Soil Res., 46:17-26, 2008. 